$\begin{array}{cc}\text { Türkiye Tarımsal Araştırmalar Dergisi } & \text { Turk J Agric Res } \\ \text { dergipark.gov.tr/tutad } & \text { 2017, 4(1): 24-30 } \\ \text { O TÜTAD } & \text { ISSN: 2148-2306 } \\ \text { e-ISSN: 2528-858X } & \text { doi: 10.19159/tutad.300701 }\end{array}$

\title{
Determination of Optimum Duration and Concentration of Stevia (Stevia rebaudiana Bert.) Seed Priming with Boric Acid $\left(\mathrm{H}_{3} \mathrm{BO}_{3}\right)^{*}$
}

\author{
Mehdi Aghighi SHAHVERDI ${ }^{1}$, Heshmat OMIDI ${ }^{2 * *}$, Seyed Jalal TABATABAEI ${ }^{2}$

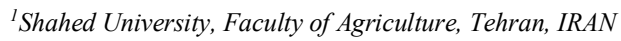 \\ ${ }^{2}$ Shahed University, Agricultural College and Medicinal Plant Research Center, Tehran, IRAN
}

\begin{abstract}
Received: 05.08 .2016
Accepted: 05.12.2016

${ }^{* *}$ Corresponding author: omidi@shahed.ac.ir

Abstract: In order to determine optimal duration and concentration of Stevia seed priming with boric acid for improving germination, an experimental factorial completely randomized design with three replications was conducted in the laboratory of Seed Science and Technology, Shahed University of Tehran in 2015. The first factor was different concentrations of boric acid $(0,0.5,1.0,1.5$ and 2.0 percent $)$ and the second factor was priming duration $(0,8,16,24$ and 32 hours). Effects of concentration and priming duration with boric acid were significant on germination percentage, mean germination time, germination rate, germination energy, germination uniformity, mean daily germination, germination daily speed, germination value, seedling length and seed vigor index. The highest values for germination percentage, germination rate, germination energy, means of daily germination, germination value and seedling vigor index were observed after 24 hours of boric acid priming. The highest germination percentage, germination rate, germination potential, germination value and seed vigor index were obtained in $2.0 \%$ boric acid priming. 24 hours priming at $1.0 \%$ concentration of boric acid had the highest germination uniformity. The seedling length was highest in 24 hours priming at $1.5 \%$ concentration of boric acid. In general, Stevia seed priming with 1.5 to $2.0 \%$ of boric acid for 24 hours had positive effects on germination indexes and seedling growth.
\end{abstract}

Keywords: Boric acid, germination, micronutrients, nutri-priming, seed vigor

\section{Introduction}

There are 17 essential elements for optimal growth and development of plants that are divided into macro and micro elements. In addition to their roles as a cofactor in enzymes and redox reactions, micronutrients have several important and vital actions in plants (Farooq et al., 2012). More importantly, micronutrients are involved in physiological key reactions of photosynthesis and respiration pathways (Mengel et al., 2001), and lack of these elements limits these vital processes and subsequently reduce productivity. For example, boron deficiency can decrease wheat (Rerkasem and Jamjod, 2004) Chickpea (Johnson et al., 2005) and lentil (Srivastava et al., 2000) productivity. Boric acid is one of the necessary elements for normal growth and development of several different plants (Abdollahi et al., 2012). Reduced productivity because of boron deficiency could be the result of a severe disturbance in metabolic reaction involved with this element, like nucleic acid, carbohydrate, proteins and indole acetic acid metabolism, cell wall biosynthesis, phenol metabolism, and preserving plasma membrane integrity and function (Tanaka and Fujiwar, 2008). Functionally boron is related to several different processes such as using calcium, cell division, flowering and fruiting, nitrogen and carbohydrate metabolism, disease tolerance, water relationships and specific catalytic reactions (Farooq et al., 2012).

Significant improvement of germination and primary growth of papaya seedlings were observed when the seeds were primed with boron solution $(2$ $\mathrm{m} \mathrm{L}^{-1}$ ) for 6 hours (Deb et al., 2010). Iqbal et al. (2012) reported wheat seed may be primed with $0.001 \%$ boron to have better and uniform stand and early seedling growth. There are different 
types of priming which used in priming experiments including hydro, halo, osmo, thermos and hormone priming, and there are different reports on this matter with different plants and different researchers (McDonald, 2000; Iqbal et al., 2012; Mirshekari, 2012; Rehman et al., 2012). Nutripriming is a relatively new method in which seeds are primed by using micro and macro nutrients, has been recently focused on (Mirshekari, 2012; Rehman et al., 2012). Nutrients as fertilizers were used by different methods such as soil application, with irrigation water or foliar fertilization (Robert et al., 2015). Using nutrients as a seed treatment by coating and seed priming are other methods that could be advantageous (Farooq et al., 2012). Seed priming by using micronutrients (enrichment) has been reported as one of the best ways to beat micronutrient deficiency (Harris et al., 1999). Seed priming with micronutrient elements results in higher rate of water absorption and metabolism and germination of seeds which consequences could be seen in higher germination rate, improvement of seedling establishment, higher resistance against stress and pest, and finally higher productivity (Memon et al., 2013).

Stevia (Stevia rebaudiana Bert.), is a perennial, herbal species of Asteraceae (Compositae) family (Hossein et al., 2008; Ucar et al., 2016). Stevia plant has a high sweetening property because of steviol glycosides (Singh and Rao, 2005) which firstly are not absorbed by the digestive system and so diabetics can use it freely, and secondly, it is not caloric, so it is adequate for obese people who have to care about their daily calorie intake. Because of its self-incompatibility, stevia pollinates by wind and insects, so the percentage of pollinated flowers is low in this plant and the seeds have low germination percentage (LiopaTsakalidi et al., 2012). Although, presented studies shows that there is no agreement for the reason of low germination ability of stevia seeds, some researchers introduce self-incompatibility as a reason for weak stevia germination (Oddone, 1997; Maiti and Purohit, 2008), while some others report that there is no self-incompatibility in this plant (Goettemoeller and Ching, 1999). Poor germination in this plant is an obstacle against large-scale planting and results in scarce a high price of an effective metabolite of this plant (Raji et al., 2015). In this research, we aimed to study the priming stevia seeds with boric acid and its effects on germination parameters and to determine the best time and favorable concentration of the priming solution of this micronutrient element.

\section{Materials and Methods}

This experiment was conducted in the Seed Science and Technology Laboratory of Agriculture college of Shahed University, using factorial experiment based on a completely randomized design with three replications, in order to determine the adequate duration and concentration for stevia seed priming with boric acid $\left(\mathrm{H}_{3} \mathrm{BO}_{3}\right)$ in 2015. Priming duration and concentration of boric acid solution were $0,8,16,24$ and 32 hours and 0 , $0.5,1.0,1.5$ and 2.0 percent respectively. Stevia seeds which were produced in 2013-2014 agricultural year were purchased from an Indian company (Global Horticulture Products) and sterilized with sodium hypochlorite $10 \%$ for $3 \mathrm{~min}$ and the rinsed with distilled water. At the end of the priming process, the seeds were washed with distilled water and dried for 24 hours in the lab. In every petri dish, 25 seeds were placed on Whatman paper, the $3 \mathrm{ml}$ water were added and to prevent water evaporation the cover of the Petri dishes were fixed and closed by parafim. Seed germination process in growth chamber was controlled on $23 \pm 2{ }^{\circ} \mathrm{C}$, photoperiod of $18 / 6$ (day/night) and relative humidity of $70 \pm 5 \%$ (Raina et al., 2013). Counting of germinated seeds starts from day 2 in a specific hour (Liopa-Tsakalidi et al., 2012) and at the end of the experiment, after 11 days, germination percentage (Liopa-Tsakalidi et al., 2012) germination rate (Pagter et al., 2009), mean germination time (Ellis and Roberts, 1981), mean of daily germination (Hoogenboom et al., 1987), daily germination speed (Stephanie et al., 2005), germination value (Ghasemi Gholozani and Dalil, 2011), germination energy (Panwar and Bhardwaj, 2005) and seed vigor index (Biradar et al., 2007) were calculated according to the equations in Table 1. Data analysis and comparison of evaluated parameters were done by SAS 9.1 and Duncan multiple range tests at 5\%, respectively.

Table 1. The computing relation of the parameters studied in the experiment

\begin{tabular}{ll}
\hline Germination Percentage (GP) & $\mathrm{GP}=(\mathrm{N} \times 100) / \mathrm{M}$ \\
Mean Germination Time (MGT) & $\left.\left.\mathrm{MGT}=\sum\right) \mathrm{Ni}\right) / \sum \mathrm{N}$ \\
Germination Rate $(\mathrm{GR})$ & $\mathrm{GR}=\sum \mathrm{Ni} / \mathrm{Ti}$ \\
Germination Energy (GE) & $\mathrm{GE}=\mathrm{Mcgr} /(\mathrm{Ni} \times 100)$ \\
Mean of Daily Germination & $\mathrm{MDG}=\mathrm{N} / \mathrm{T}$ \\
(MDG) & \\
Daily Germination Speed (DGS) & $\mathrm{DGS}=1 / \mathrm{MDG}$ \\
Germination Value (GV) & $\mathrm{GV}=\mathrm{GP} \times \mathrm{MDG}$ \\
Seed Vigor Index (SVI) & $\mathrm{SVI}=\mathrm{GP} \times \mathrm{Mean}(\mathrm{SL})$ \\
\hline
\end{tabular}

$\mathrm{N}$ : Sum of germinated seeds at the end of the experiment, M: Total planted seeds, T: Period of germination, Ti: Number of days after germination, n: Number of germinated seeds in Ti, Mcgr: Maximum cumulative germination percentage, Ni: Total seeds sown, SL: Seedling length 


\section{Results and Discussion}

\subsection{Germination percentage}

The effect of priming duration and concentration of boric acid on stevia seed germination were significant in $\mathrm{P} \leq 0.01$ (Table 2). The highest germination percentage among the priming duration and different concentration of boric acid were observed for 24 hours priming and the concentration of $2.0 \%$ with the average of 42.66 and 44 percent, respectively (Tables 3 and 4). Seed priming with boric acid $2.0 \%$ increase germination percentage by $35.72 \%$ in comparison with control. There was a significant and positive correlation at $\mathrm{P} \leq 0.01$ between germination percentage and germination rate, germination energy, seedling length, germination uniformity and germination value (Table 5). Together, these results indicate that increasing in seed germination percentage will lead to improvement of seed germination parameters in this plant, and finally will result in seed vigor index and germination energy. In agreement with our data, Bayat et al., (2015) showed significant and positive correlation between seed germination and seedling length, seed vigor, germination energy and germination rate. Mirshekari (2012) reported that Anethum graveolens L. seed germination with boric acid micronutrient have a significant effect on seed germination and boric acid $1.5 \%$ has the highest germination percentage in this plant. It should be noted that much higher concentration and longer times for seed priming with micronutrients have negative effects on seed germination parameters (Mirshekari, 2012). The concentration of the priming solution is one of the important factors in seed priming by boron element. For example, research on seed priming with boric acid solution (concentration of 2-20 mM) has been conducted in Russia, and both negative (reduction) and positive (increase) effects had been reported on germination parameters of different crops like rapeseed, sunflower, soybean, sugar beet, alfalfa, wheat and barley (Shorrocks, 1997; Rehman et al., 2012).

\subsection{Mean germination time}

Base on analysis of variance, the priming duration and priming concentration with boric acid have a significant effect on mean germination time (Table 2). Highest and lowest required time for germination observed in 32 and 8 hours of priming, respectively (5.65 and 4.50 day) (Table $3)$. Among different concentration of boric acid, $1.0 \%$ has the highest mean germination (Table 4). Mean germination time has a negative correlation and significant difference with germination rate and daily germination speed at $\mathrm{P} \leq 0.01$ (Table 5). Seed priming with boron (Nutri-priming) has advantageous effects on seed germination, mean time of germination, seedling vigor index and seedling length (Memon et al., 2013).

\subsection{Germination rate}

The effect of duration and concentration of seed priming with boric acid on germination rate was significant at $\mathrm{P} \leq 0.01$ (Table 2). Seed priming with boric acid for 24 hours increase germination rate to 31.85 percent in comparison with control (without priming) (Table 3). Highest germination rate was observed for seed priming with boric acid $2.0 \%$ with an average of 2.64 seed per day (Table 4). Except for mean time of germination, germination rate has a positive and significant correlation with other treatments at $\mathrm{P} \leq 0.01$ (Table 5). Seed priming with micronutrients results in higher rate of water absorption and consequently beginning of metabolism and seed germination which consequently produce higher germination rate (Rowse, 1995). Aghighi Shahverdi and Omidi (2015) reports that stevia seed priming for 24 hours with gibberellin hormone results in significant increase in germination rate and other germination parameters in the seeds of this plant.

Table 2. Summary of variance analysis for effect of duration $(0,8,16,24$ and $32 \mathrm{~h})$ and concentration $(0,0.5$, 1.0, 1.5 and $2.0 \%$ ) of priming with boric acid $\left(\mathrm{H}_{3} \mathrm{BO}_{3}\right)$ on Stevia (Stevia rebaudiana Bertoni) seed germination indices and seedling growth

\begin{tabular}{lccllccccccc}
\hline \multicolumn{10}{c}{ Mean square } \\
\hline SV & df & GP & MGT & GR & GE & GU & MDG & DGS & GV & SL & SVI \\
\hline PD & 4 & $283.94^{* *}$ & $2.83^{* *}$ & $2.32^{* *}$ & $0.00007^{* *}$ & $1.21^{* *}$ & $2.34^{* *}$ & $0.0043^{* *}$ & $1.32^{* *}$ & $0.092^{* *}$ & $5501874.6^{* *}$ \\
PC & 4 & $579.94^{* *}$ & $0.33^{*}$ & $1.97^{* *}$ & $0.00018^{* *}$ & $1.49^{* *}$ & $4.79^{* *}$ & $0.0006^{*}$ & $2.53^{* *}$ & $0.226^{* *}$ & $11216896^{* *}$ \\
PD $\times$ PC & 16 & $3.81^{\text {ns }}$ & $0.12^{\text {ns }}$ & $0.08^{\text {ns }}$ & $0.00001^{\text {ns }}$ & $0.17^{* *}$ & $0.03^{\text {ns }}$ & $0.0002^{\text {ns }}$ & $0.02^{\text {ns }}$ & $0.001^{* *}$ & $60269.3^{\text {ns }}$ \\
EE & 48 & 7.21 & 0.09 & 0.05 & 0.000009 & 0.002 & 0.05 & 0.0001 & 0.03 & 0.0006 & 52007.1 \\
\hline CV $(\%)$ & & 7.41 & 6.16 & 11.08 & 22.09 & 1.11 & 7.41 & 6.32 & 14.83 & 3.43 & 7.96 \\
\hline
\end{tabular}

SV: Sources of variance, PD: Priming duration, PC: Priming concentration, EE: Experimental error, CV: Coefficient of variation, df: Degree of freedom, GP: Germination percentage, MGT: Mean germination of time, GR: Germination rate, GE: Germination energy, GU: Germination uniformity, MDG: Mean daily germination, DGS: Daily germination speed, GV: Germination value, SL: Seedling length, SVI: Seedling length vigor index, ns: Non-significant, ${ }^{*}$ and ${ }^{* *}$ : Significant at $5 \%$ and $1 \%$ respectively 
Table 3. Mean comparison of Stevia (Stevia rebaudiana Bertoni) seeds germination indices under effect of different priming duration with boric acid $\left(\mathrm{H}_{3} \mathrm{BO}_{3}\right)$

\begin{tabular}{ccccccccc}
\hline $\begin{array}{c}\text { Priming duration } \\
(\mathrm{h})\end{array}$ & GP & $\begin{array}{c}\text { MGT } \\
\text { (day) }\end{array}$ & $\begin{array}{c}\text { GR } \\
\text { (seed per day) }\end{array}$ & GE & MDG & DGS & GV & SVI \\
\hline 0 & $31.46 \mathrm{~d}$ & $4.89 \mathrm{~b}$ & $1.84 \mathrm{c}$ & $0.012 \mathrm{c}$ & $2.86 \mathrm{~d}$ & $0.20 \mathrm{~b}$ & $0.93 \mathrm{~d}$ & $2135.50 \mathrm{e}$ \\
8 & $33.60 \mathrm{c}$ & $4.50 \mathrm{c}$ & $2.19 \mathrm{~b}$ & $0.012 \mathrm{c}$ & $3.05 \mathrm{c}$ & $0.22 \mathrm{a}$ & $1.05 \mathrm{~cd}$ & $2539.20 \mathrm{~d}$ \\
16 & $38.13 \mathrm{~b}$ & $4.80 \mathrm{~b}$ & $2.33 \mathrm{~b}$ & $0.014 \mathrm{~b}$ & $3.46 \mathrm{~b}$ & $0.20 \mathrm{~b}$ & $1.36 \mathrm{~b}$ & $3029.87 \mathrm{~b}$ \\
24 & $42.66 \mathrm{a}$ & $4.73 \mathrm{~b}$ & $2.70 \mathrm{a}$ & $0.017 \mathrm{a}$ & $3.87 \mathrm{a}$ & $0.21 \mathrm{~b}$ & $1.69 \mathrm{a}$ & $3757.87 \mathrm{a}$ \\
32 & $35.20 \mathrm{c}$ & $5.65 \mathrm{a}$ & $1.72 \mathrm{c}$ & $0.013 \mathrm{bc}$ & $3.20 \mathrm{c}$ & $0.17 \mathrm{c}$ & $1.15 \mathrm{c}$ & $2852.53 \mathrm{c}$ \\
\hline
\end{tabular}

In each column, means having at least one same letter are not significantly different according to Duncan's multiple range tests ( $\leq \leq 0.05$ ). GP: Germination percentage, MGT: Mean germination of time, GR: Germination rate, GE: Germination energy, MDG: Mean daily germination, DGS: Daily germination speed, GV: Germination value, SVI: Seedling length vigor index

Table 4. Mean comparison of Stevia (Stevia rebaudiana Bertoni) seed germination indices under effect of different priming concentration with boric acid $\left(\mathrm{H}_{3} \mathrm{BO}_{3}\right)$

\begin{tabular}{ccccccccc}
\hline $\begin{array}{c}\text { Priming } \\
\text { concentration } \\
(\%)\end{array}$ & GP & $\begin{array}{c}\text { MGT } \\
\text { (day) }\end{array}$ & $\begin{array}{c}\text { GR } \\
\text { (seed per day) }\end{array}$ & GE & MDG & DGS & GV & SVI \\
\hline 0 & $28.26 \mathrm{e}$ & $4.76 \mathrm{~b}$ & $1.69 \mathrm{~d}$ & $0.010 \mathrm{~d}$ & $2.56 \mathrm{e}$ & $0.21 \mathrm{a}$ & $0.74 \mathrm{e}$ & $1680.80 \mathrm{~d}$ \\
0.5 & $32.00 \mathrm{~d}$ & $4.78 \mathrm{~b}$ & $1.98 \mathrm{c}$ & $0.011 \mathrm{~cd}$ & $2.90 \mathrm{~d}$ & $0.21 \mathrm{a}$ & $0.95 \mathrm{~d}$ & $2318.67 \mathrm{c}$ \\
1.0 & $37.06 \mathrm{c}$ & $5.12 \mathrm{a}$ & $2.09 \mathrm{c}$ & $0.013 \mathrm{c}$ & $3.36 \mathrm{c}$ & $0.19 \mathrm{~b}$ & $1.26 \mathrm{c}$ & $2992.27 \mathrm{~b}$ \\
1.5 & $39.73 \mathrm{~b}$ & $4.94 \mathrm{ab}$ & $2.38 \mathrm{~b}$ & $0.016 \mathrm{~b}$ & $3.61 \mathrm{~b}$ & $0.20 \mathrm{ab}$ & $1.45 \mathrm{~b}$ & $3590.40 \mathrm{a}$ \\
2.0 & $44.00 \mathrm{a}$ & $4.97 \mathrm{ab}$ & $2.64 \mathrm{a}$ & $0.018 \mathrm{a}$ & $4.00 \mathrm{a}$ & $0.20 \mathrm{ab}$ & $1.78 \mathrm{a}$ & $3729.87 \mathrm{a}$ \\
\hline
\end{tabular}

In each column, means having at least one same letter are not significantly different according to Duncan's multiple range test ( $\mathrm{p} \leq 0.05)$

Table 5. Correlation assessment among Stevia (Stevia rebaudiana Bertoni) seed germination indices and seedling growth under different concentration and priming duration with boric acid $\left(\mathrm{H}_{3} \mathrm{BO}_{3}\right)$

\begin{tabular}{|c|c|c|c|c|c|c|c|c|c|}
\hline & GP & MGT & GR & $\mathrm{GE}$ & $\mathrm{GU}$ & $\mathrm{MDG}$ & DGS & GV & $\mathrm{SL}$ \\
\hline$\overline{\mathrm{MGT}}$ & $0.09^{\mathrm{ns}}$ & & & & & & & & \\
\hline GR & $0.85^{* *}$ & $-0.41^{* *}$ & & & & & & & \\
\hline GE & $0.99^{* *}$ & $0.09^{\text {ns }}$ & $0.85^{* *}$ & & & & & & \\
\hline GU & $0.72^{* *}$ & $-0.17^{\mathrm{ns}}$ & $0.77^{* *}$ & $0.72^{* *}$ & & & & & \\
\hline $\mathrm{MDG}$ & $0.99^{* *}$ & $0.09^{\mathrm{ns}}$ & $0.85^{* *}$ & $0.99^{* *}$ & $0.72^{* *}$ & & & & \\
\hline DGS & $-0.11^{\mathrm{ns}}$ & $-0.99^{* *}$ & $0.39^{* *}$ & $-0.11^{\mathrm{ns}}$ & $0.15^{\mathrm{ns}}$ & $-0.11^{\mathrm{ns}}$ & & & \\
\hline GV & $0.99^{* *}$ & $0.08^{\mathrm{ns}}$ & $0.85^{* *}$ & $0.99^{* *}$ & $0.71^{* *}$ & $0.99^{* *}$ & $-0.11^{\mathrm{ns}}$ & & \\
\hline SL & $0.83^{* *}$ & $0.20^{\mathrm{ns}}$ & $0.65^{* *}$ & $0.83^{* *}$ & $0.68^{* *}$ & $0.83^{* *}$ & $-0.22^{\mathrm{ns}}$ & $0.79^{* *}$ & \\
\hline SVI & $0.14^{\mathrm{ns}}$ & $0.80^{* *}$ & $0.96^{* *}$ & $0.93^{* *}$ & $0.73^{* *}$ & $0.96^{* *}$ & $-0.16^{\mathrm{ns}}$ & $0.95^{* *}$ & $0.93^{* *}$ \\
\hline
\end{tabular}

ns: Non-significant, * and **: Significant at $5 \%$ and $1 \%$ respectively, GP: Germination percentage, MGT: Mean germination of time, GR: Germination rate, GE: Germination energy, GU: Germination uniformity, MDG: Mean daily germination, DGS: Daily germination speed, GV: Germination value, SL: Seedling length, SVI: Seedling length vigor index

\subsection{Germination energy}

According to the analysis of variance (Table 2), the effect of duration and concentration of seed priming on germination energy were significant at $\mathrm{P} \leq 0.01$. Highest germination energy was for 24 hours of seed priming (0.017) and the lowest germination energy was for control (without priming $=0$ hour) and 8 hours of seed priming (Table 3). Also, highest germination energy for stevia seeds was for boric acid $2.0 \%$ with a mean of 0.018 , which show $44.44 \%$ increase in germination energy compared to the control (Table 4). Germination energy is one of the most important parameters to evaluate quality and power of the seeds, and higher germination energy shows higher quality and power of the seeds (Bayat et al., 2015).

\subsection{Germination uniformity}

The effect of priming duration, concentration and interplay between them on germination uniformity was significant (Table 2). Studies on the mean of interplay clearly indicate that highest germination uniformity was for a combination of 24 hours of priming in boric acid $1.0 \%$, and the lowest rate of germination uniformity observed at priming for 0 and 32 hours in control concentration of boric acid (Figure 1). Farooq et al. (2006) reported an improvement of $\alpha$-amylase activity ad increasing of soluble sugar as the reason for homogenous greening and germination of pretreated seeds of rice.

\subsection{Mean daily germination}

The effect of duration and concentration of priming on mean daily germination was significant 
at $\mathrm{P} \leq 0.01$ (Table 2). Highest and the lowest mean of daily germination were for 24 hours duration priming and control (zero hours), respectively (Table 3). Among different concentration, the highest rate of it was observed for seed priming with boric acid $2.0 \%$, which, in comparison with control (zero concentration) show 36.5\% increasing in the mean of it (Table 4).

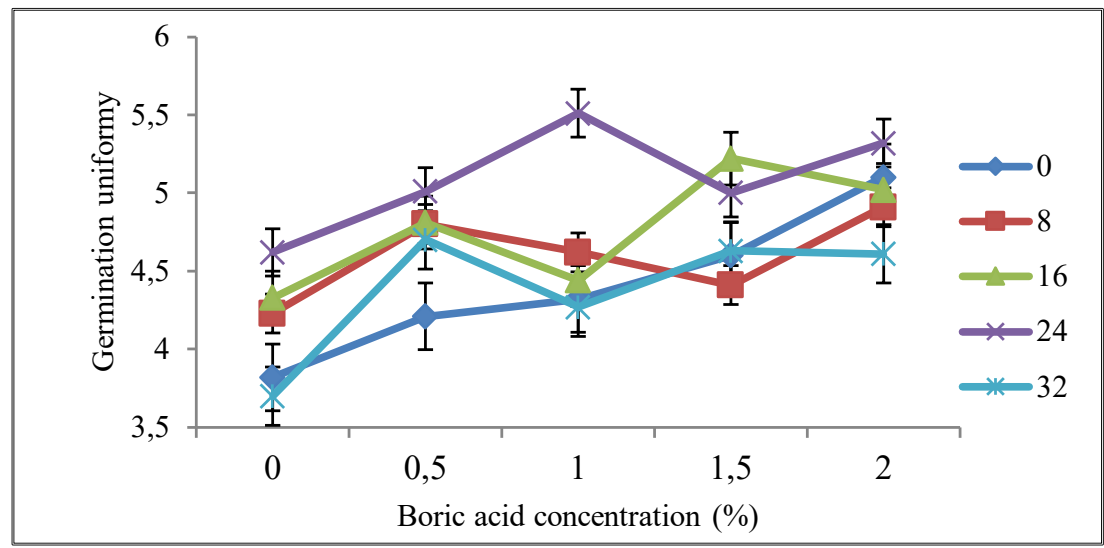

Figure 1. Mean comparison of Stevia seed germination uniformly in concentration $\times$ priming duration interaction with boric acid $\left(\mathrm{H}_{3} \mathrm{BO}_{3}\right)$

Concentration levels: 0, 0.5, 1, 1.5 and 2 percentage, Duration levels: 0, 8, 16, 24 and $32 \mathrm{~h}$

\subsection{Daily germination speed}

According to data analysis of variance (Table 2), the effect of priming duration and the concentration of boric acid were significant at $\mathrm{P} \leq 0.01$ and $\mathrm{P} \leq 0.05$, respectively. Highest daily germination speed was at 8 hours seed priming with boric acid (Table 3). Also, except for the concentration of $1.0 \%$ which has the lowest mean of daily germination speed, other concentration treatments have insignificant effect compare to each other on this parameter (Table 4). It is reported that low concentrations of boric acid which are involved in activation of enzymes like phosphatase, amylase and so on which are involved in starch metabolism, results in commencing of metabolism in seeds and increase of daily germination speed by this way (Memon et al., 2013).

\subsection{Germination value}

Data analysis results showed that the effect of priming duration and concentration seed priming on germination value was statistically significant at $\mathrm{P} \leq 0.01$ (Table 2). Seed priming for 24 hours showed the highest seed germination value, and the control time (without priming) had the lowest mean for this parameter (Table 3). Among the experimented concentrations, by increasing concentration, statistically, significant increase was observed for germination value parameter so that the 0 and $2.0 \%$ concentration have the lowest and highest mean for this parameter (Table 4).

\subsection{Seedling length}

Results of variance analysis (Table 2) showed that the effect of priming duration, priming concentration and their interaction (priming duration $\times$ priming concentration) on seedling length was statistically significant at $\mathrm{P} \leq 0.01$. Comparing the mean of the effects of interplay (Figure 2) showed that the longest $(1.02 \mathrm{~cm})$ and shortest $(0.44 \mathrm{~cm})$ seedling length observed for 24 hours seed priming with boric acid $1.5 \%$ and control (without priming) concentration, respectively. Material transport in primed seeds is high because of higher activity of enzymes involved in sucrose metabolism (sucrose synthase, invertase, sucrose phosphate synthase), so these seeds have higher biological power and germinate quicker and produce plumule and radicle, so clearly have a higher seedling length (Kaur et al., 2005).

\subsection{Seed vigor index}

According to results, the effect of priming duration and boric acid concentration on seed vigor index was statistically significant at $\mathrm{P} \leq 0.01$ (Table 2). Among the priming duration, 24 hours of seed priming and control have the highest and lowest seed vigor index. Highest seed vigor index was achieved at boric acid concentration of 1.5 and $2.0 \%$ which was $53 \%$ higher than control (Table 4). Seed vigor index have a positive correlation and statistically significance at $\mathrm{P} \leq 0.01$ with germination percentage, germination rate, germination energy, seedling length, germination 
uniformity, mean daily germination and germination value (Table 5). The importance of seedling vigor for the fast establishment and primary growth of the medicinal plant in order to compete for water, light, and minerals were emphasized in the studies of Tabrizian and Osareh (2007). Seed priming with boron micronutrients $\left(\mathrm{H}_{3} \mathrm{BO}_{3}\right)$ and iron $\left(\mathrm{FeSO}_{4}\right)$ resulted in an increase of seed vigor index in Anethum graveolens L. (Mirshekari, 2012).

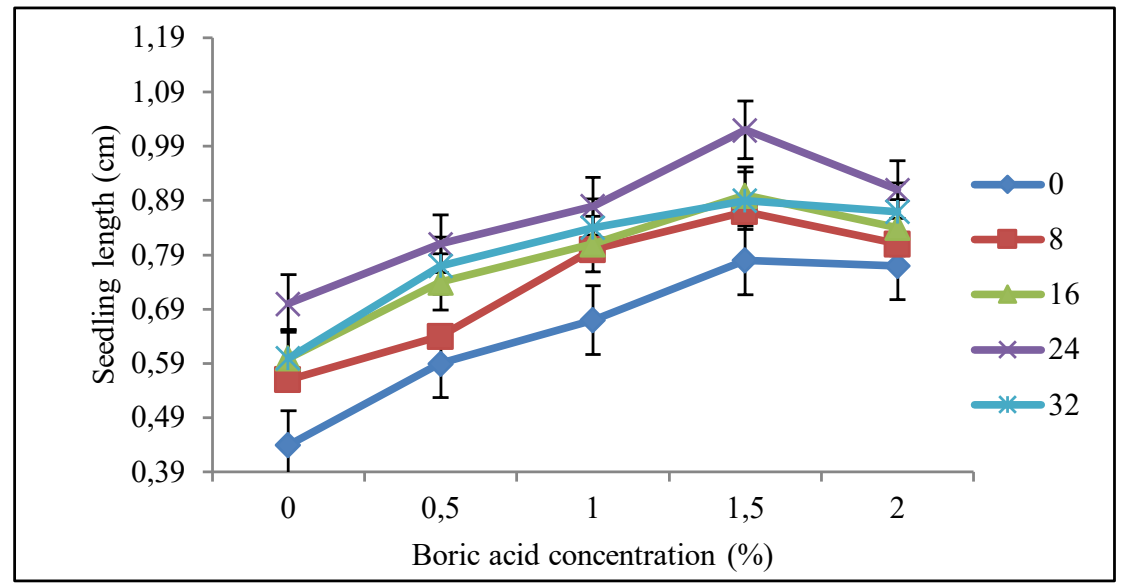

Figure 2. Mean comparison of Stevia seedling length in concentration $\times$ priming duration interaction with boric acid $\left(\mathrm{H}_{3} \mathrm{BO}_{3}\right)$

Concentration levels: 0, 0.5, 1, 1.5 and 2 percentage, Duration levels: $0,8,16,24$ and $32 \mathrm{~h}$

\section{Conclusion}

Our results showed that stevia seeds react positively to priming with boric acid, and it improved and increased germination parameters in this plant. In order to enhance seed vigor index and percentage and rate of stevia seed germination, priming with $1.5 \%$ and $2.0 \%$ concentrations of boric acid for duration 24 hours showed the best result in this experiment.

\section{References}

Abdollahi, M., Eshghi, S., Tafazzoli, E., Moosavi, N., 2012. Effects of paclobutrazol, boric acid and zinc sulfate on vegetative and reproductive growth of strawberry cv. Selva. Journal Agriculture Science Technology, 14(2): 357-363.

Aghighi Shahverdi, M., Omidi, H., 2015. Effect of hormone priming and hydropriming on germination of Stevia (Stevia rebaudiana Bertoni) under salt stress. Iranian of Seed Sciences and Research, (In Press).

Bayat, M., Rahmani, A., Amirnia, R., Ramazani, M., 2015. The effect of priming and duration of priming on germination indices and seedling characteristics of Althaea officinalis L. plant. Iranian Journal of Seed Science and Technology, 4(1): 73-82.

Biradar, K.S., Salimath, P.M., Ravikumar, R.L., 2007. Genetic variability for seedling vigor, yield and yield components in local germplasm collections of Greengram [Vigna radiata (L.) Wilczek]. Karnataka Journal Agriculture Science, 20(3): 608-609.
Deb, P., Das, A., Ghosh, S.K., Suresh, C.P., 2010. Improvement of seed germination and seedling growth of papaya (Carica papaya L.) through different pre-sowing seed treatments. Acta Horticulture, 851: 313-316.

Ellis, R.H., Roberts, E.H., 1981. The quantification of aging and survival in orthodox seeds. Seed Science and Technology, 9: 377-409.

Farooq, M., Basra, S.M.A., Warraich, E.A., Khaliq, A., 2006. Optimization of hydropriming techniques for rice seed invigoration. Seed Science and Technology, 34(2): 529-534.

Farooq, M., Wahid, A., Siddique, K.H.M., 2012. Micronutrient application through seed treatments- a review. Journal of Soil Science and Plant Nutrition, 12(1): 125-142.

Ghasemi Gholozani, K., Dalil, B., 2011. Germination and seed vigor tests. Publications Jahad Daneshgahi Mashhad.

Goettemoeller, J., Ching, A., 1999. Seed germination in Stevia rebaudiana. In: Janick, J (Eds), Perspectives on new crops and new uses. ASHS Press, Alexandria, VA, pp: 510-511.

Harris, D., Joshi, A., Khan, P.A., Gothkar, P., Sodhi, P.S., 1999. On-farm seed priming in semi-arid agriculture: Development and evaluation in maize, rice and chickpea in India using participatory methods. Experimental Agriculture, 35(1): 15-29.

Hoogenboom, G., Peterson, C.M., Huck, M.G., 1987. Shoot growth rate of soybean as affected by drought stress. Agronomy Journal, 79(4): 598-607. 
Hossein, M.A., Shamim Kabri, A.M., Jahan, T.A., Hassan, M.N., 2008. Micropropagation of Stevia rebaudiana. International Journal of Sustainable Crop Production, 3: 1-90.

Iqbal, S., Farooq, M., Nawaz, A., Rehman, A., 2012. Optimizing boron seed priming treatments for improving the germination and early seedling growth of wheat. Journal of Agriculture and Social Sciences, 8: 57-61.

Johnson, S.E., Lauren, J.G., Welch, R.M., Duxbury, J.M., 2005. A comparison of the effects of micronutrient seed priming and soil fertilization on the mineral nutrition of chickpea (Cicer arietinum), lentil (Lens culinaris), rice (Oryza sativa) and wheat (Triticum aestivum) in Nepal. Experimental Agriculture, 41(4): 427-448.

Kaur, S., Gupta, A.K., Kaur, N., 2005. Seed priming increase crop yield possibly by modulating enzymes of sucrose metabolism in chickpea. Journal of Agronomy and Crop Science, 191(2): 81-87.

Liopa-Tsakalidi, A., Kaspiris, G., Salahas, G., Barouchas, P., 2012. Effect of salicylic acid (SA) and gibberellic acid $\left(\mathrm{GA}_{1}\right)$ pre-soaking on seed germination of Stevia (Stevia rebaudiana) under salt stress. Journal of Medicinal Plants Research, 6(3): 416-423.

Maiti, R.K., Purohit, S.S., 2008. Stevia: A miracle plant for human health Agrobios (India). Jodhpur India.

McDonald, M.B., 2000. Seed priming. In M. Black, \& J. D. Bewley (Ed.). Seed Technology and Biological Basis, Black (Chapter 9, pp: 287-325). Sheffield Academic Press, England.

Memon, N.N., Gandahi, M.B., Pahoja, V.M., Sharif, N., 2013. Response of seed priming with Boron on germination and seedling sprouts of Broccoli. International Journal of Agriculture Science and Research, 3(2): 183-194.

Mengel, K., Kirkby, E.A., Kosegarten, H., Appel, T., 2001. Principles of plant nutrition. Kluwer Academic Publishers, Dordrecht, the Netherlands.

Mirshekari, B., 2012. Seed priming with iron and boron enhances germination and yield of dill (Anethum graveolens). Turkish Journal of Agriculture and Forestry, 36(1): 27-33.

Oddone, B., 1997. How to Grow Stevia. Technical Manual. Guarani Botanicals, Pawtucket, CT.

Pagter, M., Bragato, C., Malagoli, M., Brix, H., 2009. Osmotic and ionic effects of $\mathrm{NaCl}$ and $\mathrm{Na}_{2} \mathrm{SO}_{4}$ salinity on Phragmites australis. Aquatic Botany, 90(1): 43-51.

Panwar, P., Bhardwaj, S.D., 2005. Handbook of practical forestry, Agrobios (INDIA).
Raina, R., Bhandari, S.K., Chand, R., Sharma, Y., 2013. Strategies to improve poor seed germination in Stevia rebaudiana, a low calorie sweetener. Journal of Medicinal Plants Research, 7(24): 1793-1799.

Raji, A.A., Mohammad, B.O., Zarina, B.Z., 2015. Acclimatized apparatus enhanced seed germination in Stevia rebaudiana Bertoni. International Journal of Biology, 7(2): 28-34.

Rehman, A., Farooq, M., Cheema, Z.A., Wahid, A., 2012. Role of boron in leaf elongation and tillering dynamics in fine grain aromatic rice. Journal of Plant Nutrition, 38(3): 338-354.

Rerkasem, B., Jamjod, S., 2004. Boron deficiency in wheat: A review. Field Crops Research, 89(2-3): 173-186.

Robert, L.M., Timothy, K.H., Rusan, M.J., 2015. Challenges of increasing water and nutrient efficincy in irrigated agriculture, Chaper 8 of "Managing water and fertilizer for sustainable agricultural intensification", International Fertilizer Industry Association, pp: 168-186.

Rowse, H.R., 1995. Drum priming: A non-osmotic method of priming seeds. Seed Science and Technology, 24: 281-294.

Shorrocks, V.M., 1997. The occurrence and correction of boron deficiency. Plant and Soil, 193(1): 121148.

Singh, S.D., Rao, G.P., 2005. Stevia: the herbal sugar of $21^{\text {st }}$ century. Sugar Technology, 7(1): 17-24.

Srivastava, S.P., Bhandari, T.M.S., Yadav, C.R., Joshi, M., Erskine, W., 2000. Boron deficiency in lentil: Yield loss and geographic distribution in a germplasm collection. Plant and Soil, 219(1): 147151

Stephanie, E.B., Svoboda, V.P., Paul, A.T., Marc, W.V.I., 2005. Controlled drought affects morphology and anatomy of Salvia splendens. Journal of American Society for Horticultural Science, 130(5): 775-781.

Tabrizian, F., Osareh, A.M., 2007. Improved seed emergence and yield related traits of marigold (Calendula officinalis L.) by on-farm seed micronutrient treatment trials. Iranian Journal of Crop Science, 9: 124-141.

Tanaka, M., Fujiwar, T., 2008. Physiological roles and transport mechanisms of boron: Perspectives from plants. Pflügers Archiv-European Journal of Physiology, 456(4): 671-677.

Ucar, E., Ozyigit, Y., Turgut, K., 2016. The effects of light and temperature on germination of Stevia (Stevia rebaudiana Bertoni) Seeds. Turkish Journal of Agricultural Research, 3(1): 37-40. 